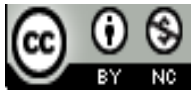 \\ Jurnal Terapan Manajemen dan Bisnis is licensed under \\ A Creative Commons Attribution-Non Commercial 4.0 International License.
}

\title{
TRANSFER PRICING DECISIONS AT MULTINATIONAL COMPANIES IN INDONESIA: TAX EXPENSES, FOREIGN OWNERSHIP, INTANGIBLE ASSETS
}

\author{
Anggun Budi Utami S Depari "), Reza Ramadhan, Amrie Firmansyah \\ *) Polytechnic of State Finance STAN, Banten, Indonesia \\ E-mail: amrie.firmansyah@gmail.com
}

\begin{abstract}
This study aims to examine the effect of tax expenses, foreign ownership on transfer pricing decisions. This study employs quantitative methods. This study's data type is secondary data from the financial statements of manufacturing companies listed on the Indonesia Stock Exchange (IDX) from 2017 to 2019. Data were obtained from the Indonesia Stock Exchange's official website at http: //www.idx.co.id. Sampling was conducted by purposive sampling technique with a final sample of 30 observations. Hypothesis testing is done by multiple regression analysis with panel data. This study concludes that tax expenses and intangible assets are positively associated with transfer pricing decisions, while foreign ownership is not associated with transfer pricing decisions. This study indicates that Indonesia's Tax Authority needs to exercise tighter supervision on MNCs with intangible assets.
\end{abstract}

Keywords: Taxes, Transfer Pricing, Intangible Assets, Foreign Ownership

\section{Introduction}

Globalization, economic development, and business competition in an increasingly fast world have influenced business schemes and business actors. The development of the business world has encouraged the growth of national companies into multinational companies. Multinational companies operate across national borders and have unique relationships, either because of equity participation, management control, or technology, in the form of subsidiaries, branch companies, agents, etc., to maximize profit after tax (Suandy, 2016). There have been various international transactions between members (divisions) of this affiliated multinational company, for example, the sale of goods or services. This transaction is the leading cause of transfer pricing practices. Transfer pricing is a pricing policy used in transactions between companies with related parties (Barker et al., 2017). For multinational companies, transfer pricing is necessary to ensure that transactions with their foreign-affiliated companies are carried out efficiently and track their divisions' performance (Rugman \& Eden, 2017). Transfer pricing becomes a problem for the government if the MNC deliberately adjusts related parties' prices for tax advantage purposes. According to Rugman and Eden (2017), the transfer pricing dispute between MNC and the government arises from a fundamental difference between business and government entities' roles. The MNE is responsible for efficient operation management while the government has the authority to collect taxes. Taxes 
significantly impact a company's net income and cash flow through their influence on foreign investment decisions, financial structure, capital cost determination, etc. However, transfer pricing is also widely misused for corporate tax avoidance (Handayani \& Widyanti, 2017). MNC takes advantage of existing tax regulatory loopholes to minimize taxes. Transfer pricing in goods or services sales transactions is carried out by reducing the selling price between companies in one group and transferring the profits earned to companies domiciled in countries that apply low tax rates (Cahyadi \& Noviari, 2018). This condition can enhance the tax authorities' problems to maximize revenue from the tax sector, which is the state budget source. The Directorate General of Taxes as the Indonesian Tax Authority explained that digital progress and the impact of its disruption has had a direct effect on the transformation of the international taxation landscape and indirectly through the globalization variable (https://ekonomi.bisnis.com). Digitalization accelerates the globalization process, thereby increasing the volume and size of transactions across jurisdictions. It is estimated that around $60-70 \%$ of the jurisdictional transactions are transactions conducted by multinational companies (www.taxjustice.net). The global challenge faced by almost all tax authorities related to this development is the impact of transfer pricing practices, one of which is tax disputes. In a report covering 89 jurisdictions, 2018 Mutual Agreement Procedure (MAP) Statistics, the OECD noted that the number of transfer pricing disputes increased by $20 \%$.

Transfer pricing is a significant issue in international taxation. Likewise, an understanding of transfer pricing is becoming increasingly urgent, and the development of global business patterns and transactions between multinational companies has increased drastically and is much more complicated. The case of tax avoidance through transfer pricing schemes has always been in the global spotlight, and tax disputes resulting from transfer pricing transactions are also growing. The Ministry of Finance of the Republic of Indonesia noted that around 2000 companies owned by foreigners did not pay their taxes for ten years, so that the state suffered Rp. 500 trillion in losses (Kusumawati, 2016). Besides, the unavailability of standard regulations causes transfer pricing checks to be often won by taxpayers in tax courts so that multinational companies are increasingly motivated to carry out transfer pricing (Julaikah, 2014 in Refgia, 2017). In resolving a transfer pricing case, the tax authorities must first detect a special relationship to a transaction, then analyze and prove any irregularities in the selling or buying price between the affiliated parties. Based on the Regulation of the Director-General of Taxes Number PER-32/PJ/2011, the fair price in transfer pricing is the price or profit that occurs in a transaction made between parties who have no special relationship in comparable conditions or a price that is determined as a price comply with the fairness and arm's length principle. This principle is based on the norm that the price of a transaction made by unrelated parties is determined by market forces so that the transaction reflects a fair market price. In transfer pricing, the arm's length principle is used as a guideline for determining a multinational company's transfer price. The Indonesia Ministry of Finance issued a new regulation as an alternative to the resolution of transfer pricing disputes through the Minister of Finance Decree Number 22/PMK.03/2020 dated 18 March 2020 concerning Procedures for Implementing Advance Pricing Agreements. The previous decree was PMK Number 7/PMK.03/2015 dated January 12, 2015. This regulation is a form of the government's commitment to implementing the Action Plan 14 of the OECD/G20 Base Erosion and Profit Shifting (BEPS) Project, implementing more effective provisions, and providing certainty. Previously, through Indonesia Ministry Finance, the government had also implemented PMK-213/PMK.03/2016, which stipulated that corporate taxpayers conducting transactions with affiliated parties had an obligation to submit a summary of transfer pricing 
documentation (TP Doc). This regulation is also a form of implementation of the OECD recommendations in the BEPS Action Plan 13. The issuance of these regulations shows the government's seriousness in facing the transfer pricing scheme to prevent the loss of potential taxes that support $80 \%$ of total state revenue. There are many studies on transfer pricing, as in Arham et al. (2020). Previous studies have been conducted using tax expenses (Sulistyawati et al., 2020; Tiwa et al., 2017; Kiswanto and Purwaningsih, 2014; Nazihah et al., 2019; Fitri et al., 2019; Refgia, 2017; Noviastika. et al., 2016; Indrasti, 2016; Saifudin and Putri, 2018; Jumaidi et al., 2017; Khotimah, 2018; Pratiwi, 2018; Halil et al., 2019; Herawaty and Anne, 2017; Jafri and Mustikasari, 2018; Rosa et al., 2017; Rachmat, 2019), Tunneling Incentive (Sulistyawati et al., 2020; Nazihah et al., 2019; Susanti \& Firmansyah, 2018; Refgia, 2017; Noviastika et al., 2016; Saifudin and Putri, 2018; Jumaidi et al., 2017; Khotimah, 2018; Pratiwi, 2018; Herawaty and Anne, 2017; Jafri and Mustikasari, 2018; Rosa et al., 2017), Bonus Mechanism (Sulistyawati et al., 2020; Nazihah et al. ., 2019; Fitri et al., 2019; Susanti \& Firmansyah, 2018; Refgia, 2017; Indrasti, 2016; Saifudin and Putri, 2018; Herawaty and Anne, 2017; Rosa et al., 2017; Rachmat, 2019), Ownership Foreign (Tiwa et al ., 2017; Kiswanto and Purwaningsih, 2014; Fitri et al., 2019; Refgia, 2017; Indrasti, 2016; Halil et al., 2019), Company Size (Kiswanto and Purwaningsih, 2014; Waworuntu and Hadisaputra, 2016; Nazihah et al., 2019; Refgia, 2017; Khotimah, 2018; Halil et al., 2019), Profitability (Waworuntu and Hadisaputra, 2016; Jumaidi et al., 2017; Halil et al., 2019), Leverage (Waworuntu and Hadisaputra, 2016; Indrasti, 2016; Pratiwi, 2018; Rosa et al., 2017; Firmansyah and Yunidar, 2020), Multinationality (Waworuntu and Hadisaputra, 2016; Dinca and Fitriana, 2019), Intangible Assets (Waworuntu and Hadisaputra, 2016; Dinca and Fitriana, 2019; Jafri and Mustikasari, 2018; Firmansyah and Yunidar, 2020), Good Corporate Governance (Noviastika et al., 2016; Jumaidi et al., 2017; Halil et al., 2019; Sari, 2020; Dinca dan Fitriana, 2019; Herawaty dan Anne, 2017; Rosa et al., 2017).

This study examines the effect of taxes, foreign ownership, and intangible assets on transfer pricing decisions. According to research conducted by Sulistyawati et al. (2020), taxes have a significant positive effect on the transfer pricing decisions of companies. It is also in line with the results of Rachmat's (2019) research that the practice of transfer pricing is believed to reduce the potential for tax revenue of a country. Taxes are considered an expense that can reduce company profits so that management carries out tax planning and even tax avoidance. Companies carry out transfer pricing from a tax perspective to minimize the tax expenses by manipulating or restructuring transfer prices between companies with a special relationship through corporate tax planning (Tiwa et al., 2017). This price engineering is carried out by reducing the selling price between companies in one group and transferring the profits earned to companies domiciled in countries that apply low tax rates. Another reason is that multinational companies shift their income to countries with lower tax rates in which their affiliated companies operate. In general, transfers between affiliated companies in multinational companies result in lower tax expenses (Sulistyawati et al., 2020). However, Rosa et al. (2017) found that taxes have no positive effect on transfer pricing. The inconsistency of the previous test results resulted in an investigation of the tax expenses on transfer pricing decisions requiring further investigation.

Furthermore, there are several forms of ownership in the ownership structure, foreign ownership. Foreign ownership arises because of foreign investment, which according to Indonesian Act Number 25 of 2007 article 1 paragraph (6) concerning Investment is defined as an investment activity to conduct business in the Republic of Indonesia, which is carried out by foreign investors using foreign capital, Wholly or jointly with domestic investors. Transfer 
pricing is a transaction carried out by a company with foreign parties, so foreign shareholders who control the company influence its decision to carry out transfer pricing (Tiwa et al., 2017). A controlling shareholder is an entity that owns shares of $20 \%$ or more directly or indirectly so that the entity is considered to have a significant influence in controlling the company (PSAK 15, 2015). Research by Fitri et al. (2019) and Halil et al. (2019) concluded that foreign ownership positively affects the company's transfer pricing decision. The high level of foreign ownership will affect transfer pricing practices. A large number of foreign shareholdings can put shareholders in a strong position to control the company, including implementing transfer pricing policies.

Meanwhile, Tiwa et al. (2017) found that foreign ownership does not affect its transfer pricing decisions. The percentage of foreign ownership in a company is not a benchmark in applying transfer pricing. Testing inconsistencies in previous studies results has resulted in retesting foreign ownership of transfer pricing decisions is necessary. Intangible assets are nonmonetary assets that can be identified without their physical form. These assets are held for use in producing or delivering goods or services, for lease to other parties, or administrative purposes. (PSAK 19, 2010). Company managers can utilize intangible assets as assets that are difficult to detect to fulfill their interests. The company can transfer intangible assets to its subsidiaries or affiliated companies. This condition will be easy to do in multinational companies. The ease with which multinational companies transfer intangible assets will increase company managers' motivation to transfer pricing, especially for companies with considerable intangible assets.

Jafri and Mustikasari (2018) found that intangible assets do not affect transfer pricing behavior. The results of this study are in line with Ohnuma and Kato (2015). The number of intangible asset transactions does not reflect its management's opportunistic actions in transfer pricing behavior. The valuation of intangible assets is also not straightforward because determining the value under the same conditions must be done with a third or independent party. However, on average, transactions of intangible assets are carried out with one group or related parties. However, the results of Waworuntu and Hadisaputra's (2016) research regarding the determinants of transfer pricing aggressiveness in Indonesia state that intangible assets have a negative effect on a company's transfer pricing decisions. Transfers from intangible assets pose a significant risk to transfer pricing aggressiveness because of the variability in interpreting the value of intangible assets and the difficulty in determining the intangible assets involved in the transaction. Another study conducted by Firmansyah and Yunidar (2020) resulted in different conclusions: that intangible asset transactions positively affect transfer pricing aggressiveness. This research states that the increase in a company's intangible asset transactions causes transfer pricing's aggressiveness to increase. These four studies produced mixed conclusions. The possibility that underlies this difference is the proxy for calculating the effect of intangible assets on transfer pricing. Therefore, the previous research results' inconsistency resulted in a re-examination of intangible assets against the transfer pricing decision needed to be done.

This study's control variables are company size (Herawaty and Anne, 2017; Firmansyah and Yunidar, 2020) and leverage (Aryotama and Firmansyah, 2019; Dewi and Noviari, 2017). The company's size is used by considering companies with more prominent affiliations have a more incredible opportunity in tax planning through transfer pricing. Leverage is used as a control variable because company debt is closely related to its interest 
expense. The high-interest expense can reduce the profit earned by the company. Companies with a high level of debt utilization will prioritize their focus on debt repayments, which impact corporate decision-making decisions, including transfer pricing. This study uses financial statement data from manufacturing companies included in the category of multinational companies listed on the Indonesia Stock Exchange in the 2017-2019 period because transfer pricing is usually only carried out by multinational companies. When viewed from its characteristics, multinational companies tend to choose certain business activities that are footloose industry (industries that are not bound by location), generally owned by manufacturing companies, so that many manufacturing companies in Indonesia are multinational companies.

\section{Literature Review}

\section{Positive Accounting Theory}

This theory explains the factors that influence management in choosing optimal accounting procedures and have unique reasons. According to Kusuma and Wijaya (2017), accounting procedures are used by companies that are not the same as one another, and companies are given the freedom to choose alternative procedures that can be done to minimize costs and maximize the value of company contracts so that they are related to the company's transfer pricing practices. Transfer pricing is carried out to minimize company costs in the form of paid taxes. Scott (2015) stated that accounting theory is positively related to company managers' prediction of accounting policy decisions and how managers respond to the latest accounting standards. Positive accounting theory assumes that managers have rational traits such as investors, and managers will choose accounting policies that provide benefits for themselves. Management can choose various motivations in order to get benefits. Positive accounting theory provides three hypotheses of management motives in increasing company profits from opportunistic actions (Watts and Zimmerman, 1986). Three hypotheses describe this opportunistic behavior according to Watts and Zimmerman (1986). First, the bonus plan hypothesis. Managers will be motivated by the bonus policy that the company owner will implement. If the owner determines the bonus calculated based on profit, the manager can be motivated to do better, but it is also possible that the manager will commit managerial fraud.

Managers will tend to report the highest possible profit by using accounting policies that maximize profit. Second, the debt covenant hypothesis deals with the conditions that the company must meet in the debt agreement. This hypothesis states that the closer a company is to violating debt agreements, the more likely it is that company managers will choose accounting procedures that can shift future earnings to the present period. It is a game of profit so that the lending party does not get information on the company's real condition because the provision of debt generally depends on the ratios in the financial statements, which are affected by profit. Third, the political cost hypothesis states that large companies with high-profit levels are often the object of implementing government regulations and policies, such as imposing high-income taxes. It causes managers to choose accounting policies that shift current earnings to future periods to reduce political costs, reducing corporate profits by reducing taxable income. Based on the three hypotheses, the bonus plan hypothesis can influence transfer pricing decisions. According to this hypothesis, the manager's motive is that managers tend to increase company profits if the bonus is calculated based on the amount of profit earned. It can lead to fraud, one of which is by minimizing the tax expenses using transfer pricing practices to increase company profits. Besides, The Political Cost Hypothesis also greatly influences transfer pricing decisions. Political costs in the form of taxes imposed by the government are 
determined based on its profits. This condition encourages managers to manage profit in a certain amount so that the tax imposed is not too high, which can be done by avoiding taxes through transfer pricing practices. Management of company profits by using transfer pricing in sales transactions of goods or services is carried out by reducing the selling price between companies in one group and transferring profits to companies domiciled in countries that apply low tax rates (Cahyadi \& Noviari, 2018).

\section{Hypothesis Development}

Based on positive accounting theory, a political cost hypothesis states that the more significant its political costs, the greater the tendency for companies to use accounting methods to reduce their profits. Companies intend to reduce the government's attention regarding the imposition of high taxes as a factor that increases political costs. This reason could be a possible relationship between taxes and transfer pricing. High tax payments make companies avoid taxes. One of the tax avoidance practices for multinational companies is transfer pricing. In transfer pricing activities, multinational companies with several branches in various countries tend to shift their tax obligations from countries with high tax rates to countries that apply low tax rates (Refgia, 2017). The higher the country's tax rate, the more likely the company will carry out transfer pricing. The results of Sulistyawati et al. (2020) state that taxes have a significant positive effect on companies' transfer pricing decisions. It is also in line with the results of research by Indrasti (2016), Noviastika et al. (2016), Tiwa et al. (2017), Jafri and Mustikasari (2018), Khotimah (2019), and Nazihah et al. (2019). The company's motive is to maximize profit, one of the ways is by minimizing expenses. In general, companies identify tax payments as an expense to use transfer pricing practices to minimize the tax expenses. Therefore, the first hypothesis in this study is as follows:

$\mathrm{H}_{1}$ : Tax expenses are positively associated with transfer pricing decisions.

Foreign ownership is the ownership of shares owned by foreign individuals or institutions. Asian companies, especially in Indonesia, use a concentrated ownership structure. Concentrated ownership structures tend to create conflicts of interest between controlling shareholders and management and non-controlling shareholders (Refgia, 2017). When the share ownership owned by the foreign controlling shareholder is greater, the foreign controlling shareholder has a more significant influence in determining various decisions in the company, including pricing policies and the number of transfer pricing transactions (Tiwa et al., 2017). The foreign controlling shareholder sells the company's products he controls to his private company at below-market prices. Foreign controlling shareholders do this to gain personal gain and disadvantage non-controlling shareholders (Atmaja, 2011). Research conducted by Indrastri (2016), Refgia (2017), Fitri et al. (2019), and Halil et al. (2019) stated that foreign ownership has a positive and significant effect on the company's transfer pricing decision. The high level of foreign ownership will affect transfer pricing practices. A large number of foreign shareholdings can put shareholders in a strong position to control the company, including implementing transfer pricing policies. Therefore, the second hypothesis in this study is as follows.

$\mathrm{H}_{2}$ : Foreign ownership has a positive effect on transfer pricing decisions.

Based on positive accounting theory, a bonus plan hypothesis states that companies that use bonus planning will undoubtedly use an accounting method to increase their recorded profits for a given period. Due to the difficulty of measuring the value of intangible assets, the transfer value of intangible asset payments, for example, royalties, also becomes challenging to 
measure at a fair price according to the arm's length principle. It will motivate managers to commit managerial fraud by playing with the size of the numbers in the financial statements, in this case, the transfer value of intangible assets so that they always get a bonus because it has increased the company's profitability.

Multinational companies will strategically reallocate their intangible assets to business units located in countries with low tax rates, and one example is receiving royalty payments from affiliated companies located in countries with high tax rates (Dudar et al., 2015). The valuation of intangible assets is still subjective because there is no comparative data available to measure transfer value's suitability based on market value.

Transfer of intangible assets poses a significant risk to the aggressiveness of transfer pricing due to differences in interpreting the valuation and the difficulty in determining the accuracy of the value of intangible asset transactions that occurs (Grubert, 2003). It is supported by previous research conducted by Firmansyah and Yunidar (2020), which results that intangible asset transactions positively affect transfer pricing aggressiveness. The increase in a company's intangible asset transactions causes transfer pricing's aggressiveness to increase. There is a possibility that there is a relationship between intangible assets and the company's consideration of transfer pricing. Therefore, the third hypothesis in this study is as follows: $\mathrm{H}_{3}$ : Intangible assets have a positive effect on transfer pricing.

\section{Methodology}

This research employs quantitative methods. The type of data processed in this study is secondary data. The data used is in the form of financial statements of manufacturing companies listed on the Indonesia Stock Exchange (IDX) from 2017 to 2019. Data were obtained from the official website of the Indonesia Stock Exchange at the address http://www.idx.co.id. Besides, this study is a research that uses panel data (pooled data). Sampling was conducted by purposive sampling technique, namely with the following criteria:

Table 1 Research Sample

\begin{tabular}{lc}
\hline Criteria & Amount \\
\hline All manufacturing companies listed on the Indonesia Stock Exchange in June & 187 \\
2020 & -30 \\
Manufacturing companies registered after January 1, 2017 & -19 \\
Manufacturing companies that have consecutive incomplete Financial & \\
Statements for 2017 s.d. 2019 & -90 \\
Manufacturing companies that do not report intangible assets in the Statement & \\
of Financial Position & -15 \\
Manufacturing companies that do not report consecutive net income in 2017 & -21 \\
s.d. 2019 & -2 \\
Manufacturing companies not owned by foreign parties $\geq 20 \%$ & 10 \\
Manufacturing companies that do not disclose receivables from related parties & 30 \\
The amount of company data used in the study & \\
Total sample &
\end{tabular}

Source: Processed 
The dependent variable used in this study is the transfer pricing decision. Transfer pricing decisions are measured by comparing receivables from related parties with the company's total receivables (Kusuma and Wijaya, 2017). The choice of the dependent variable proxy refers to previous research by Khotimah (2018).

$$
\text { Transfer Pricing }=\frac{\text { Receivables from related parties }}{\text { Total Receivables }}
$$

The independent variables consist of taxes, foreign ownership, and intangible assets. This study uses the Effective Tax Rate (ETR) as a tax proxy, referring to Sulistyawati et al. (2020), Tiwa et al. (2017), Waworuntu, and Hadisaputra (2016).

$$
\text { ETR }=\frac{\text { Tax Expense }- \text { Deferred Tax Expense }}{\text { Pretax Incom }}
$$

Where ETR $=$ Effective tax rate

Foreign ownership proxy is measured following the proportion of ordinary shares held by foreigners, as Tiwa et al. (2017), Fitri et al. (2019), and Refgia (2017):

$$
\text { Foreign ownership }=\frac{\text { Total foreign ownership }}{\text { Total shares outstanding }}
$$

Intangible Assets proxy follows Firmansyah and Yunidar (2020) as follows:

$$
\text { Intangible Assets }=\frac{\text { Total Intangible Assets }}{\text { Total Assets }}
$$

Besides, this study uses control variables consisting of firm size and leverage. The company's size is used by considering companies with more prominent affiliations have a more incredible opportunity in tax planning through transfer pricing. In this study, company size is measured by the logarithm of total assets, which refers to Waworuntu and Hadisaputra (2016), Nazihah et al. (2019), Aryotama and Firmansyah (2019), and Firmansyah and Yunidar (2020).

$$
\text { Size }=\text { logarithm Total Assets }
$$

Leverage shows how much debt is used to finance the company (Waworuntu and Hadisaputra, 2016). The choice of leverage as a control variable refers to Pratiwi (2018), Waworuntu and Hadisaputra (2016), and Firmansyah and Yunidar (2020), as follows:

$$
\text { Leverage }=\frac{\text { Total Debts }}{\text { Total Assets }}
$$

Hypothesis testing is conducted using multiple regression with panel data.

The research model is as follows:

$$
\text { TP }=\alpha+\beta 1 \text { ETRit }+\beta 2 \text { FOROWNit }+\beta 3 \text { INTANit }+\beta 4 \text { SIZEit }+\beta 5 \text { LEVit }+\varepsilon i t
$$

Where:

TP Transfer Pricing Decisions

ETRit: Company tax I year $\mathrm{t}$

FOROWNit: Foreign ownership of company I year $t$ 
INTANit: Intangible Assets company I year t

SIZEit: Company size I year $\mathrm{t}$

LEVit: Leverage company I year $t$

cit: Error.

\section{Results and Discussions}

In summary, the descriptive analysis of the variables used in this study is presented in the following table.

Tabel 2 Descriptive Statistical Analysis

\begin{tabular}{lcccccc}
\hline & TP & ETR & INTANG & FOROWN & LEV & SIZE \\
\hline Mean & 0.1769 & 0.2562 & 0.0180 & 0.5536 & 0.3900 & 13.1097 \\
Median & 0.0715 & 0.2602 & 0.0122 & 0.5100 & 0.3963 & 12.9735 \\
Max & 0.9631 & 0.3821 & 0.0668 & 0.9246 & 0.7442 & 14.5465 \\
Min. & 0.0014 & 0.0042 & 0.0037 & 0.2078 & 0.1492 & 12.2151 \\
Std. Dev. & 0.2494 & 0.0701 & 0.0176 & 0.2102 & 0.1644 & 0.71393 \\
\hline
\end{tabular}

Source: Processed

Furthermore, the multiple regression test for panel data model selection is to use the common effect model. The test results are as follows:

Table 2 Summary of Hypothesis Test

\begin{tabular}{ccccc}
\hline Variable & Coeff. & t-Stat. & Prob. & \\
\hline C & 2.3940 & 6.3166 & 0.000 & $* * *$ \\
\hline ETR & -0.4753 & -2.3190 & 0.014 & $* *$ \\
INTANGASSET & 4.4914 & 4.3789 & 0.000 & $* * *$ \\
KEPASING & -0.5493 & -7.4213 & 0.000 & $* * *$ \\
LEV & 0.1816 & 1.7178 & 0.049 & $* *$ \\
SIZE & -0.1500 & -5.3220 & 0.000 & $* * *$ \\
R $^{2}$ & 0.7555 & & & \\
Adj. R & 0.7045 & & & \\
F-stat. & 14.833 & & & \\
Prob(F-stat.) & 0.0000 & & & \\
\hline
\end{tabular}

Source: Processed

\section{The association between tax expenses and transfer pricing}

This study indicates that the tax expenses are negatively associated with transfer pricing decisions. The result of this study is in line with Khotimah (2018). The result indicates that the more tax expenses, the more cautious companies make transfer pricing decisions and tend to reduce the company's transfer pricing decisions. Besides, the supervision of tax officers on companies with high tax expenses will be tighter. When associated with positive accounting theory, this study's result confirms the political cost hypothesis. The hypothesis states that large companies with high-profit levels are widely used to implement government regulations and policies, such as high-income taxes. A high-profit rate will lead to a high tax expense as well. Thus the higher the profit, the higher the tax expenses, the greater the government's supervision of the company.

On the other hand, it is not certain that companies with lower tax expenses will not carry out transfer pricing activities. Based on the political cost hypothesis, it can be assumed that companies that have lower profits will be less likely to be the object of government policy 
implementation so that they have less supervision. The Indonesia Minister of Finance Decree Number 213/PMK.03/2016 regulates the criteria for Taxpayers obliged to organize and keep Transfer Pricing Documents. In article 2 paragraph (2c), it is stated that Taxpayers conducting affiliated transactions with Affiliated Parties who are in a country or jurisdiction with an income tax rate lower than the income tax rate as referred to in Article 17 of Indonesia Act Number 7 of 1983 concerning Income Tax as amended several times, most recently by Indonesia Act Number 36 of 2008 concerning the Fourth Amendment of Act Number 7 of 1983 concerning Income Tax, it is obligatory to organize and keep Transfer Pricing Documents in the form of master documents and local documents. In this study, companies that are the object of research are multinational companies. After making observations, all sample companies are affiliated with a country with an income tax rate lower than Indonesia's income tax rate. One of the affiliated countries in this study sample is Singapore, which has a corporate income tax rate of $17 \%$. Thus, all samples in this study have an obligation to keep the government's transfer pricing documents required. This document helps the Indonesia Tax Authority carry out compliance monitoring, inspection, preliminary evidence checking, or taxpayer investigations. The company's transfer pricing activities can be monitored in this document. The obligation to keep this document can also be suspected as a management consideration to make transfer pricing decisions more careful.

\section{The association between foreign Ownership and Transfer Pricing Decisions.}

This study states that foreign ownership is not associated with transfer pricing decisions. The result of this study is in line with the research of Tiwa et al. (2017). The percentage of foreign ownership in a company is not a benchmark in applying transfer pricing. The desire to control foreign shareholders to improve personal welfare is irrelevant because the sample companies' foreign ownership is not blood relatives. Expropriation is not easy to do because managerial decision-making requires approval from the board of directors. Large foreign ownership in a multinational company also does not necessarily mean that foreign shareholders are in a strong position to control the company, including applying transfer pricing policies. The existence of other non-foreign controlling shareholders may influence transfer pricing decisions.

If associated with the bonus plan hypothesis, management can also take a role in transfer pricing decisions. Management who is directly involved in carrying out accounting recording activities and company operations will influence transfer pricing. Management will be given incentives or bonuses if, in an accounting period, company profits show good results. Moreover, transfer pricing can be done by manipulating transfer prices between entities in the accounting records so that if the board approves the transfer pricing of directors, transfer pricing can be implemented. Foreign ownership also does not affect transfer pricing decisions because it is suspected that foreign shareholders already understand international taxation and its consequences. Transfer pricing is one of the BEPS (Base Erosion and Profit Shifting) schemes so that the OECD, together with the G20, formulate an action plan and take concrete steps to overcome the problem of state losses caused by the BEPS. Minister of Finance Regulation number PMK-213/PMK.03/2016, compared to the OECD Transfer Pricing Guidelines, is also inline (parallel). Thus, it is suspected that foreign shareholders do not want to take high risks in implementing the transfer pricing policy. If the company fails to meet the standards and is monitored by the tax authorities, the company will incur higher costs in terms of additional taxes, interest, and fines imposed by the tax authorities, affecting its reputation. This condition 
is also in line with The Political Cost Hypothesis, which states that companies tend to reduce the spotlight or excessive government supervision to reduce political costs.

\section{The association between Intangible Assets and Transfer Pricing}

The result of this study indicates that intangible assets are positively associated with transfer pricing decisions. The result of this study is in line with Firmansyah and Yunidar (2020). An increase in the company's intangible assets can lead to increased transfer pricing aggressiveness. Some cases regarding transfer pricing with intangible assets can involve trademarks, service marks, or intellectual property. The parent company registers intangible assets that are created to transfer prices to a subsidiary in a country at a low tax rate. Intangible assets are one of the problematic assets to detect by tax officials so that company managers can use them to fulfill their interests by transferring to have a strong relationship with the company with a lower tax rate. This condition will be easy to do in multinational companies that are the sample of this study, where multinational companies have strong relationships with overseas companies that company shareholders own. The ease with which multinational companies can transfer intangible assets will increase company managers' motivation to transfer pricing actions. This result is also in line with the bonus plan hypothesis, which states that management will use an accounting method to increase the recorded profit because it has a bonus policy. With the difficulty of measuring intangible assets' value, the transfer value of intangible assets payments such as royalties is also challenging to measure at a fair price according to the arm's length principle. Besides, Firmansyah and Yunidar (2020) stated that identifying intangible assets is also tricky because not all intangible assets are protected by law registered and recorded in books. In the context of transfer pricing, each party must receive reasonable compensation for their contributions. It will motivate employees to carry out transfer pricing because company profitability can be achieved. One way is to arrange the figures in the financial statements in such a way, for example, by allocating intangible assets to low-tax countries using the transfer pricing mechanism.

The regulation regarding transfer pricing in Indonesia, namely PMK213/PMK.03/2016, although it is parallel to the OECD Transfer Pricing Guidelines, there are still weaknesses in its implementation. Even though taxpayers have filled in the Special Attachment to the Special Relationship Transaction Statement on the annual notification letter, many taxpayers do not understand or pretend not to understand transfer pricing (Putri, 2018). Besides, Putri (2018) stated that the Directorate General of Taxes has not optimally monitor fraud committed on transfer pricing transactions because it does not have the necessary buying and selling data. Of course, it also motivates management to be more aggressive in carrying out transfer pricing, especially for intangible asset transactions whose measurements are subjective and therefore difficult for tax authorities to measure.

\section{Conclusions}

With the increasing tax expenses imposed, the more cautious companies make transfer pricing decisions and reduce their transfer pricing decisions. The government has issued a new regulation requiring companies to keep documents or information related to transfer pricing. On the other hand, companies with lower tax expenses cannot be ascertained not to carry out transfer pricing activities because it can be assumed that fewer companies will be the object of implementing government policies so that their supervision will be less. The percentage of foreign ownership in a company is not a benchmark in applying transfer pricing. The sample companies' foreign ownership is not in the form of blood relatives, so expropriation is not 
straightforward. Besides, non-foreign shareholders and management can also influence transfer pricing decisions. An increase in the company's intangible assets can lead to increased transfer pricing aggressiveness. Intangible assets are challenging to detect and measure at a fair price by tax officials so that company managers can use them to fulfill their interests by transferring to have a strong relationship with the company with a lower tax rate. Companies that set bonus policies will motivate management to adjust the numbers in the financial statements to achieve company profitability by allocating intangible assets to low-tax countries using the transfer pricing mechanism.

This study has limitations; the sample used is a multinational manufacturing company so that it cannot generalize the findings for all companies listed on the Indonesia Stock Exchange. This study only uses limited observations for three years, from 2017 to 2019. Future research expects to add variables that can influence transfer pricing decisions that have not been studied, such as profitability, good corporate governance, and earnings management. Future researchers are expected to expand the research sample for more accurate results. This study indicates that the Indonesia Tax Authority can improve taxation rules regarding intangible assets. Besides, The Authority can expand the compliance monitoring of Taxpayers conducting transfer pricing. Supervision of transfer pricing activities is carried out on companies with enormous tax expenses and taxpayers with lower tax expenses because lower tax expenses do not guarantee that companies do not carry out transfer pricing.

\section{References}

Arham, A., Firmansyah, A., \& Nor, A.M.E. (2020). Penelitian Transfer Pricing di Indonesia: Sebuah Studi Kepustakaan. Jurnal Online Insan Akuntan, 5(1), 57-72

Barker, J., Asare, K., \& Brickman, S. (2017). Transfer pricing as a vehicle in corporate tax avoidance. Journal of Applied Business Research, 33(1), 9-16.

Cahyadi, A. S., \& Noviari, N. (2018). Pengaruh Pajak, Exchange Rate, Profitabilitas, dan Leverage pada Keputusan Melakukan Transfer Pricing. E- Jurnal Akuntansi Universitas Udayana, 24(2), 1441-1473.

Dinca, M. H., \& Fitriana, V. E. (2019). Do R\&D Expenditure, Multinationality and Corporate Governance Influence Transfer Pricing Aggressiveness? Jurnal Akuntansi Dan Bisnis : Jurnal Program Studi Akuntansi, 5(2), 102.

Firmansyah, A., \& Yunidar, A. (2020). Financial Derivatives, Financial Leverage, Intangible Assets, and Transfer Pricing Aggressiveness: Evidence from Indonesian Companies. Jurnal Dinamika Akuntansi dan Bisnis 7(1), 1-14.

Fitri, D., Hidayat, N., \& Arsono, T. (2019). The Effect Of Tax Management, Bonus Mechanism And Foreign Ownership On Transfer Pricing Decision. Jurnal Aplikasi Ekonomi, Akuntansi Dan Bisnis, 1(1), 36-48.

Halil, A., Herawati, T., \& Hermanto. (2019). Pengaruh pajak, kepemilikan asing, spesialisasi keahlian auditor pajak, ukuran perusahaan, gross profit margin terhadap keputusan untuk melakukan transfer pricing. Open Journal Systems, 14(12), 2-8.

Handayani, E., \& Widyanti, Y. (2017). Pengaruh Pajak, Mekanisme Bonus, Kepemilikan Asing, Exchange Rate Terhadap Transfer Pricing (Perusahaan Manufaktur Di BEI). Seminar Hasil Penelitian FEB, 84-95.

Herawaty, V., \& Anne, A. (2019). Pengaruh tarif pajak penghasilan, mekanisme bonus, dan tunneling incentives terhadap pergeseran laba dalam melakukan transfer pricing dengan good corporate governance sebagai variabel moderasi. Jurnal Akuntansi Trisakti, 4(2), 141. 
IAI. (2017). PSAK 15: Investasi pada Entitas Asosiasi dan Ventura Bersama. Jakarta: Ikatan Akuntan Indonesia.

IAI. (2015). PSAK 19: Aset Tak berwujud. Jakarta: Ikatan Akuntan Indonesia.

Indrasti, A. W. (2016). Pengaruh Pajak, Kepemilikan Asing, Bonus Plan dan Debt Covenant Terhadap Keputusan Perusahaan Untuk Melakukan Transfer Pricing (Studi Empiris Pada Perusahaan Manufaktur yang Terdaftar di Bursa Efek Indonesia Tahun 20122015). PROFITA, 9(3), 348-371.

Jafri, H. E., \& Mustikasari, E. (2018). Pengaruh perencanaan pajak, tunneling incentive dan aset tidak berwujud terhadap perilaku transfer pricing pada perusahaan manufaktur yang memiliki hubungan istimewa yang terdaftar di Bursa Efek Indonesia periode 2014-2016. Berkala Akuntansi Dan Keuangan Indonesia, 3(2), 63.

Jumaidi, L. T., Bambang, B., \& Hudaya, R. (2018). Analisis pajak, tunneling, gross margin, dan kap spesialis terhadap keputusan untuk melakukan transfer pricing. Jurnal Aplikasi Akuntansi, 1(2), 1-21.

Khotimah, S. K. (2018). Pengaruh Beban Pajak, Tunneling Incentive, dan Ukuran Perusahaan Terhadap Keputusan Perusahaan Dalam Melakukan Transfer Pricing (Studi Empiris pada Perusahaan Multinasional yang Listing di Bursa Efek Indonesia Tahun 2013 2017). Jurnal Ekobis Dewantara, 1(12), 125-138.

Kiswanto, N., \& Purwaningsih, A. (2014). Pengaruh Pajak, Kepemilikan Asing, dan Ukuran Perusahaan terhadap Transfer Pricing pada Perusahaan Manufaktur di Bei Tahun 2010-2013. Jurnal Ekonomi Akuntansi Universitas Atma Jaya, 1-15.

Kusumawati, U. D. (2016). https://m.cnnindonesia.com/ekonomi/20160321201016-92118883/menkeu-dua-ribu-perusahaan-asing-tak-bayar-pajak

Noviastika, D., Mayowan, Y., \& Karjo, S. (2016). Pengaruh pajak, tunneling incentive, dan good corporate governance $(\mathrm{gcg})$ terhadap indikasi melakukan transfer pricing pada perusahaan manufaktur yang terdaftar di Bursa Efek Indonesia (Studi pada Bursa Efek Indonesia yang Berkaitan dengan Perusahaan Asing). Jurnal Perpajakan, 8(1), 19.

OECD. (2018). http://www.oecd.org/tax/dispute/mutual-agreement-procedure-statistics.htm

Ohnuma, H., \& Kato, K. (2015). Empirical examination of market reaction to transfer pricing taxation announcement in press: a Japanese perspective. Journal of Modern Accounting and Auditing, 11(1), 10-26.

Pratiwi, B. (2018). Pengaruh Pajak, Exchange Rate, Tunneling Incentive, Dan Leverage Terhadap Transfer Pricing. Jurnal Ekonomi Dan Bisnis, 19(3), 90.

Putri, W. A. (2018). Prinsip Kewajaran dan Dokumen sebagai Penangkal Kecurangan Transfer Pricing di Indonesia. Jurnal Riset Akuntansi dan Keuangan, 6(1), 1-10

Refgia, T., Ratnawati, V., \& Rusli, R. (2016). Pengaruh Pajak, Mekanisme Bonus, Ukuran Perusahaan, Kepemilikan Asing, Dan Tunneling Incentive Terhadap Transfer Pricing (Perusahaan Sektor Industri Dasar Dan Kimia Yang Listing Di BEI Tahun 2011-2014). Jurnal Online Mahasiswa Fakultas Ekonomi Universitas Riau, 4(1), 543-555.

Rosa, R., Andini, R., \& Raharjo, K. (2017). Pengaruh Pajak, Tunneling Incentive, Mekanisme Bonus, Debt Covenant dan Good Corporate Governance (GCG) Terhadap Transaksi Transfer Pricing (Studi pada Perusahaan Manufaktur yang terdaftar di Bursa Efek Indonesia tahun 2013 - 2015). Journal of Accounting, 3(3), 1-19.

Rugman, A., \& Eden, L. (2017). Multinationals and Transfer Pricing. Routledge. ISBN10:1138242810, ISBN-13:978- 1138242814

Rustiarini, N. W. (2011). Pengaruh Struktur Kepemilikan Saham pada Pengungkapan Corporate Social Responsibility. AUDI Jurnal Akuntansi dan Bisnis, 6(1), 1-24. 
Saifudin, \& Putri, L. S. (2018). Determinasi Pajak, Mekanisme Bonus, Dan Tunneling Incentive Terhadap Keputusan Transfer Pricing Pada Emiten Bei. Agregat: Jurnal Ekonomi Dan Bisnis, 2(1), 32-43.

Sari, D. K. (2020). Transfer Pricing Aggressiveness and Corporate Governance: Indonesia's Evidence. Advances in Social Science, Education and Humanities Research, 426(Icvhe 2018), 69-77.

Scott, W. R. (2015). Financial Accounting Theory, 7th Edition. USA: Pearson.

Simamora, B. E. P. P., \& Hermawan, A. A. (2018). Transfer Pricing Analysis on Intra-Group Services and the Related Transfer Pricing Disputes from Indonesian Tax Perspectives. Advances in Economics, Business and Management Research, 55(7), 24-28.

Sissandhy, A. K., \& Sudarno, A. (2014). Pengaruh kepemilikan asing terhadap nilai perusahaan dengan pengungkapan corporate social responsibility sebagai variabel intervening. Diponegoro Journal of Accounting, 3, 2, 34-40.

Suandy, E. (2016). Perencanaan Pajak (6 Ed.). Jakarta: Salemba Empat

Sulistyawati, A. I., Santoso, A. S., \& Rokhawati, L. (2020). Determinant Detection Of Transfer Pricing Decisions. Accountability, 9(1), 16-27.

Susanti, A., \& Firmansyah, A. Determinants of transfer pricing decisions in Indonesia manufacturing companies. Jurnal Akuntansi dan Auditing Indonesia, 22(2), 81-93

Tiwa, E. M., Saerang, D. P. E., \& Tirayoh, V. Z. (2017). Pengaruh Pajak Dan Kepemilikan Asing Terhadap Penerapan Transfer Pricing Pada Perusahaan Manufaktur Yang Terdaftar Di BEI Tahun 2013-2015. Jurnal EMBA: Jurnal Riset Ekonomi, Manajemen, Bisnis Dan Akuntansi, 5(2), 2666-2675.

Waworuntu, S. R., \& Hadisaputra, R. (2016). Determinants of Transfer Pricing Aggressiveness in Indonesia. Pertanika J. Soc. Sci. \& Hum., 24, 95-110. 